\title{
THE ROLE OF CITY BRANDING ON VISITORS' REVISIT INTENTION: A STUDY IN MALANG, INDONESIA
}

\author{
Tita Imamelina Mujihestia ${ }^{1}$, Ananda Sabil Hussein ${ }^{2}$ \\ Eka Afnan Troena ${ }^{3}$ \\ 1,2,3 Faculty of Economics and Business, University of Brawijaya, \\ Malang, Indonesia
}

tita imam@yahoo.com

\begin{abstract}
The main purpose of this paper is to investigate the influence of city branding on visitors' revisit intention to Malang city which is well-known as a holiday destination in Indonesia. Study about city branding has been conducted by many researchers before, but study that applied in an enclave city, like Malang, has not been thoroughly examined. In order to make this study result becomes a guideline to design proper marketing strategies, this study will focused on the impact of three city branding attributes that is city image, city authenticity and city uniqueness on visitors' revisit intention. This study uses a quantitative research method. The primary data were obtained using a questionnaire addressed to the visitors' who chose Malang city as their holiday destination. Results indicate that city branding has a relationship with visitors' revisit intention and city image plays an important role on the relationship.

Keywords: city branding, city image, city authenticity, city uniqueness, revisit intention
\end{abstract}

JEL : M31;M37

DOI $: 10.24002 /$ kinerja.v22i1.1239

Received : 08/08/2017 Reviewed : 01/03/2018 Final Version : 15/03/2018 


\section{INTRODUCTION}

Over the past six decades, tourism activities continue to growth and become one of the biggest and the fastest economic sector in the world. Globally, the number of foreign tourists has increased from 674 million people in 2000 to 1.186 million people in 2015 (UNWTO, 2016). Indonesia also experienced the same. The number of foreign tourists who visited Indonesia in 2015 has increased $97 \%$ comparing to those on 1997 (Indonesia Central Bureau of Statistics, 2016) and the number of domestic tourists' trip in 2013 increased 8.8\% from those on 2009 (Ministry of Tourism, 2017). Some effective strategies have been set by many cities to accommodate this phenomenon. One of the strategies that are still considered as the important and the effective is city branding.

City branding which is regarded as a strategic instrument to publicize a city's competitive advantages, becomes a common practice to market the city's history, quality of place, lifestyle and culture for opportunity, prestige or power in capital accumulation in a competitive environment (L. Zhang \& Zhao 2009; Langer, 2001; Morgan et al., 2002; Berci et al., 2002; Evans, 2003). City branding is the idea of discovering or creating some uniqueness, which differentiates one city from others in order to gain a competitive brain value (Ashworth, 2009).

Malang city, which is used as the case study in this research, is the second largest city in East Java and well-known as one of the famous tourism destination in Indonesia. Malang city location can be described as enclave city due to its location surrounded by Malang district and Batu city which also famous with their tourism destination. This situation required Malang city for having an effective strategy to push their tourism destination position in the competition. One of the strategies that already conducted by the local government was launched the new city branding in 2015 named "Beautiful Malang", which means that Malang is a really pretty and beautiful city, feasible to live and study and has a various culture and culinary (Head of Tourism Department in Aminudin Muhammad, Detik.com, 2016).

In order to make this research focused, three attributes which considered as the most suitable to illustrate the characteristic of Malang city were chosen to describe city branding, that is city image, city uniqueness and city authenticity. Malang city is famous with its image, such as beautiful scenery, architecture and various culinary to be chosen. Malang also well-known with its authentic tourism, that visitors' easily can find a building or house with ancient architecture. And the last is Malang has a various unique holiday destination that visitors' can't find in other city such as thematic kampong in several cities' corner.

Even though similar research as this has been conducted before, however there are still some inconsistencies about those studies results. The study of Gurbuz, 2008 established a significant relationship between branding activity and revisit intention while So et al., 2013 confirms otherwise. Contradict founding are also found in the relationship between image and revisit intention. Kim \& Lee, 2015; H.Chou, 2013; H.Qu et al., 2011; Pratminingsih et al., 2014 shows any 
positive relationship between image and revisit intention, however RamseookMunhurrun et al., 2015 indicate there is no significant relationship.

Apart of the inconsistent findings among studies above, the objective of this paper is to examine the influence of city branding to visitors revisit intention by focusing on those three city branding elements. To date, there is no published study has been found in investigating the relationship of those three city branding element and revisit intention into one study. This paper aims to clarify that limitation and minimize the possibilities of overlapping studies as no research has simultaneously compared the influence of those constructs towards visitors' revisit intention in tourism sector, especially for enclave city. This gap has generated a new call for researchers to examine them (Cronin et al., 2000; Robinson et al., 2011).

From a theoretical perspective, this study will extend our understanding on the role of city branding on visitors revisit intention. From a practical perspective, these findings could help the tourism destination stakeholder such as tourism operators, local tourism organizations and government to create a sustainable strategy to develop their tourism destination.

\section{LITERATURE REVIEW}

\subsection{City Branding (CB)}

The American Marketing Association (AMA) defines a brand as a name, term, design, symbol or a combination of them intended to identify the goods and services of one seller or group of sellers and to differentiate them from those of other sellers. A brand is therefore more than a product, because it can have dimensions that differentiate it in some way from other products designed to satisfy the same need (Keller, 2013). Specifically, Ashworth (2009) adjust the definition of place branding as the idea of discovering or creating some uniqueness, which differentiates one place from others in order to gain a competitive brand value.

City branding activity is something common and popular to be used for city to compete with others (L. Zhang \& Zhao, 2009). It's supported by Kavaratzis \& Ashworth (2007) whom stated that almost every city has city branding activity on their agenda which aim to rebuild their city image, because city branding still consider as one of the most effective marketing strategies. Due to tight competition among countries promoting their tourism destination, a city has to rethink about what the city offers and will offer in the future, rethink about what can be created that is so valuable about the city that its businesses, institutions and residents want to remain, that will attract investors, visitors and talent and that will make commentators and influencers recommend the city (Van Gelder, 2008).

Accordingly, L. Zhang \& Zhao (2009) stated that city branding has to be concerned with how culture and history, economic growth and social development, infrastructure and architecture, landscape and environment, among other things, can be combined into a saleable identity that is acceptable to all people. City branding itself has some attributes, such as image, authenticity, uniqueness, culture, identity, history, infrastructure and architecture, economic growth, social development, landscape and environment (Hatch \& Schultz, 2002; L. Zhang \& 
Zhao, 2009; Riza et al., 2012) and when researchers discuss about that, it can't be separated from three factors which plays important roles in city branding that is product, producers and consumer (Kavaratzis \& Ashworth, 2005). This make a conclusion that city branding is not government responsibilities only but also others related stakeholder in order to deliver a consistent message about city to external parties.

\subsubsection{City Image (Cl)}

With the importance of image for a place or destination to attract the visitors' intention, some studies and research already conducted. Kotler et al., (1993) defined place image as the sum of beliefs, ideals and impressions people have toward a certain place. That consumer perception then reflected as an image that memorized on customer mind (Keller, 2013). For a destination or city, image holds a critical role to create the positive and recognizable brand identity. It is an important variable for visitors' satisfaction and revisit intention (Pratminingsih et al., 2014).

Accordingly, Baloglu \& Brinberg (1997) and Basaran (2016) suggested, place image consist of three components: cognitive, affective and conative. Cognitive refers to individual own knowledge and beliefs about the destination, affective is defined as individual feelings toward a destination or as an emotional response of individuals to a place and conative is how one acts on the information and how they feel about a destination. Basaran (2016) found out that image, including all the components, can be used to predict visitors behavioral intentions toward destination in the future such as visitors revisit intention and visitors willingness to recommend the destination to others and giving positive word of mouth. Kim \& Lee (2015), Pratminingsih (2014) studies also supported this theory and found out that good city image plays an important role to increase visitors revisit intention.

\subsubsection{City Uniqueness (CU)}

In order to have good brand positioning in the market, such brand should have ability to compete or have some unique selling value, hence customer will have some reason to choose that brand (Keller, 2013). For a city, almost every city has their own uniqueness which build from visitors' memory and image, whether positive or negative (Riza, 2012). Kavaratzis \& Ashworth (2005) suggested place or tourism destination needs to be differentiated through unique brand identity if it wants to be recognized as existing, perceived in the minds of visitors' as possessing qualities superior to those of competitors and consumed in a manner commensurate with the objectives of the place. Uniqueness can be created and founded to support city branding activity (Ashworth, 2009). Culinary, music or even slogan such as "New York City, City that never sleeps" and "Seattle, Emerald City" can be sold as the uniqueness (Kemp et al., 2012).

Accordingly, visitors who have positive image about the destination, including the uniqueness of the destination, will have a higher probability to revisit the destination and recommend the destination to others. 


\subsubsection{City Authenticity (CA)}

Authenticity is a part of marketing strategy and one of the important components that support city branding (Beverland et al., 2008). It is a universal value that can motivate tourists' for visiting such destination (Mc Cannel, 1973; Cohen, 1988; Naoi, 2004; Kolar \& Zabkar, 2007). Steiner \& Reisinger (2006) suggest that authenticity can be used to represent comprehensive judgement decision which affect by social belief, hope, preference and social background or tourists personal perception. Authenticity is more than just original, genuine and real (Jones, 2010 and MKono, 2012).

There are three approaches to measure authentic and authenticity: the characteristic, verification degree (experience) and state of being. Related to tourism, those approaches engage with toured objects, tourism sites and touristic experiences (Boyd, 2012). Hyojin \& Bonn (2015) suggested three different approaches to authenticity: objective authenticity, constructive authenticity and existential authenticity. Objective authenticity described as a museum-linked usage of the authenticity of the original. Constructive authenticity described as the result of social construction, while existential authenticity described as personal or intersubjective feelings activated by liminal process of tourists' activity. In addition, there are, also, three key dimensions of brand authenticity, which is being the category pioneer, adhering to principles and maintaining the original product.

\subsection{Revisit Intention (RI)}

Other variable to be measured in this paper is visitor revisit intention. Previously, there are many studies used this as their variable. Some studies relate this variable with visitors' satisfaction. Chen \& Tsai (2007) described revisit intention as visitors' judgement about the likeliness to revisit the same destination. Some reasons that influenced visitors' judgment are visitors' desirable emotion to the destination find a match in self-congruity, visitors' memory and visitors' experienced (Kim \& Lee, 2015; Barnes et al., 2016). Lee (2015) strengthen those theory by mentioned that the more visitors' satisfied with a destination, the more possibilities for them to revisit the destination and even recommend it to others.

Based on previous studies above, visitors' revisit intention can be divided into two dimensions: behavioral dimension and attitudinal dimension. Behavioral dimension represent consumers' decision to revisit the destination and attitudinal dimension represent the whole customers' behavior, not only their intention to revisit but also the possibilities for them to recommend the destination to others (Getty \& Thompson, 1994; Bowen \& Shoemaker, 1998; Kandapully \& Suhartanto, 2000).

\subsection{Conceptual Framework and Research Hypotheses}

The conceptual framework is constructed in fig. 1. The model presented in fig. 1 proposes that city image directly results in visitors' revisit intention; city uniqueness directly results in visitors' revisit intention; and city authenticity directly results in revisit intention. 


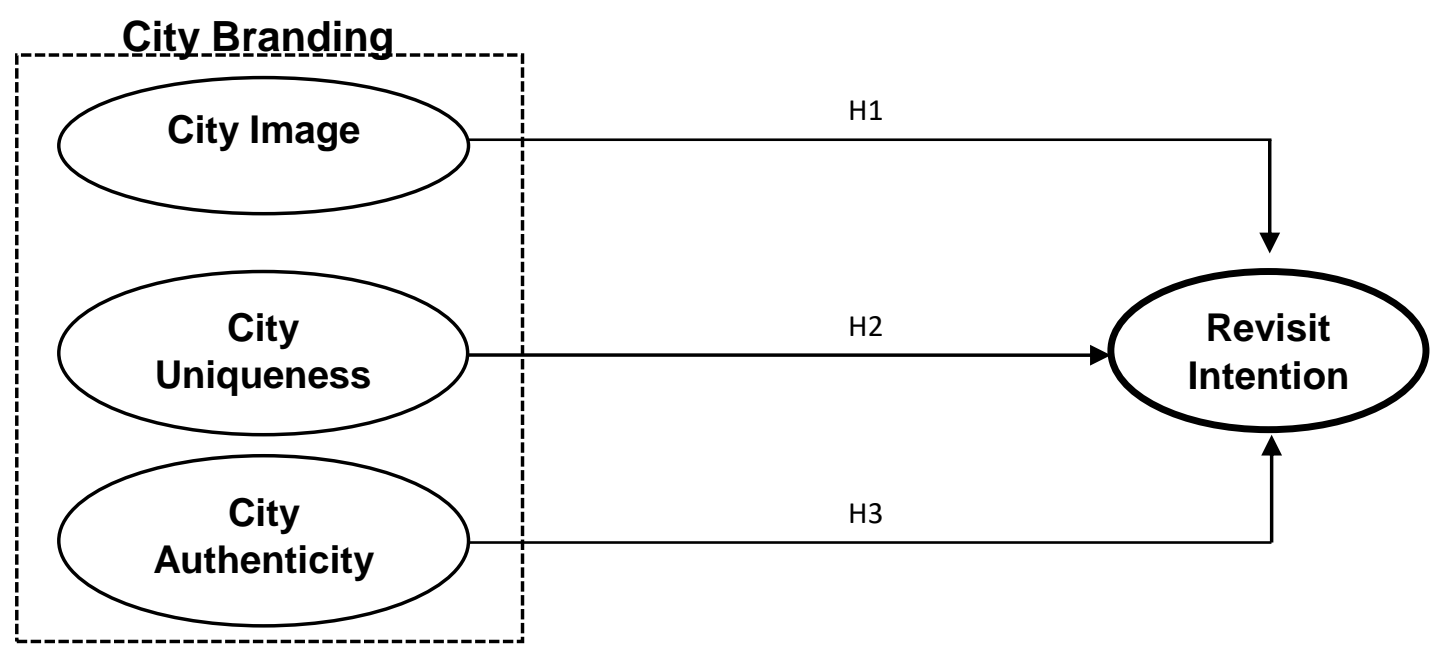

Figure 1. Conceptual Framework

H1: City Image significantly influences Visitors' revisit intention.

H2: City Uniqueness significantly influences Visitors' revisit intention.

H3: City Authenticity significantly influences Visitors' revisit intention.

\section{METHODOLOGY}

Data were collected during April 2017 from visitors' who visited Malang for holiday reason from January 2015 to April 2017. The time period has been chosen due to Malang city branding "Beautiful Malang" launched even time held on 2015 and by the time respondents considering have the similar image about Malang. This survey used a convenient sampling approach. On-site and on-line surveys were administered. Only visitors who completed their trip were asked to participate in this study. A total of 205 questionnaires were given out and all were returned, among which, 180 were used for data analysis and 25 were removed due to unqualified with the respondent criteria, representing an $87.81 \%$ response rate. This final sample size is considered sufficient to generate stable solutions using Partial Least Square (PLS) approach for data analysis (Chin \& Newsted, 1999). The respondents profile can be seen on table 1 .

\subsection{Survey Instrument}

A self-administered questionnaire was created to address the effect of city image as well as collect behavioral intentions and demographic information. This studied used five point Likert-type scale, ranging from $1=$ strongly disagree to $5=$ strongly agree. The scale was used to obtain information about the effect of city image, city authenticity and city uniqueness related to visitor experiences while visiting Malang city. Using the same measurement, information was also gathered pertaining to visitors' behavioral intention to revisit Malang city. A total of 16 questions were developed and used to obtain visitors' data. 
Table 1. Respondents Profile

\begin{tabular}{|c|c|c|}
\hline Variable & Frequency & Percentage \\
\hline \multicolumn{3}{|l|}{ Gender } \\
\hline Male & 76 & 42 \\
\hline Female & 104 & 58 \\
\hline \multicolumn{3}{|l|}{ Age } \\
\hline $18-25$ & 11 & 6 \\
\hline $26-35$ & 83 & 46 \\
\hline $36-50$ & 56 & 31 \\
\hline 50 and above & 30 & 17 \\
\hline \multicolumn{3}{|l|}{ Education } \\
\hline Senior high school & 7 & 4 \\
\hline College degree & 13 & 7 \\
\hline University degree & 126 & 70 \\
\hline Master degree & 34 & 19 \\
\hline \multicolumn{3}{|l|}{ Occupations } \\
\hline Student & 3 & 2 \\
\hline Public service & 62 & 34 \\
\hline Private company employee & 63 & 35 \\
\hline Professionals & 15 & 8 \\
\hline Housewives & 30 & 17 \\
\hline Others & 7 & 4 \\
\hline \multicolumn{3}{|l|}{ Place of Origin } \\
\hline Jakarta & 48 & 26 \\
\hline Surabaya & 54 & 30 \\
\hline $\begin{array}{l}\text { Other city in east Java } \\
\text { (except Surabaya and } \\
\text { Malang) }\end{array}$ & 32 & 18 \\
\hline Other city in Indonesia & 46 & 26 \\
\hline \multicolumn{3}{|l|}{ Number of visits } \\
\hline 1 time & 33 & 18 \\
\hline 2 times & 83 & 46 \\
\hline Above 5 times & 64 & 36 \\
\hline
\end{tabular}

Sources: Primary data are processed, 2017

A set of questionnaire adapted from prior studies were used to collect seven items on city image (Boo et al., 2010; Sirgy \& Su, 2000; Lin, 2011; Cesya Rizkika P \& Ananda, 2014), four items on city uniqueness (Netemeyer et al., 2004; Kemp et al., 2012) three items on city authenticity (Hyojin \& Bonn, 2015; Ram et al., 2016) and two items on revisit intention (Quintal \& Polczynski, 2010)

\section{RESULT AND DISCUSSION}

\subsection{Model Measurement}

There are two evaluation steps that were used in this measurement model: evaluation of outer model and evaluation of inner model. 


\subsubsection{Evaluation of Outer Model}

The evaluation of outer model in this study is used to test the validity and reliability of the indicators and latent variables. Validity test is measured using two indicators namely convergent validity and discriminant validity. Convergent validity is measured by employing outer loadings from each indicator which the cut of value is higher than 0.6. Convergent validity can also be measured by using the value of Average Variance Extracted (AVE) which value of AVE for each latent variable should be higher than 0.5 .

While convergent validity can be checked by using outer loading and AVE, discriminant validity is indicated by value of cross loadings for each latent variable that should not be higher than any other variables. To have a robust measurement, PLS technique also requires a model to have internal consistencies among used items. In this study, internal consistency is measured by composite reliability (all latent variable $>0.7$ ).

Table 2. Results Summary for Validity and Reliability Test

\begin{tabular}{|c|c|c|c|c|}
\hline $\begin{array}{c}\text { Latent } \\
\text { Variable }\end{array}$ & Indicators & Loadings & AVE & $\begin{array}{l}\text { Composite } \\
\text { Reliability }\end{array}$ \\
\hline \multirow{7}{*}{ City Image $(\mathrm{Cl})$} & Cl1 & 0.862940 & \multirow{7}{*}{0.767765} & \multirow{7}{*}{0.958570} \\
\hline & $\mathrm{Cl} 2$ & 0.879219 & & \\
\hline & $\mathrm{Cl} 3$ & 0.865992 & & \\
\hline & $\mathrm{Cl} 4$ & 0.872889 & & \\
\hline & $\mathrm{Cl} 5$ & 0.889416 & & \\
\hline & $\mathrm{Cl} 6$ & 0.864964 & & \\
\hline & $\mathrm{Cl} 7$ & 0.897531 & & \\
\hline \multirow{4}{*}{$\begin{array}{c}\text { City } \\
\text { Uniqueness } \\
\text { (CU) }\end{array}$} & CU1 & 0.844497 & \multirow{4}{*}{0.806961} & \multirow{4}{*}{0.943506} \\
\hline & CU2 & 0.913843 & & \\
\hline & CU3 & 0.908681 & & \\
\hline & CU4 & 0.924045 & & \\
\hline \multirow{3}{*}{$\begin{array}{c}\text { City } \\
\text { Authenticity } \\
(\mathrm{CA})\end{array}$} & CA1 & 0.784623 & \multirow{3}{*}{0.696947} & \multirow{3}{*}{0.873208} \\
\hline & CA2 & 0.853553 & & \\
\hline & CA3 & 0.864092 & & \\
\hline \multirow{2}{*}{$\begin{array}{c}\text { Revisit } \\
\text { Intention (RI) }\end{array}$} & Rl1 & 0.951744 & \multirow{2}{*}{0.913885} & \multirow{2}{*}{0.955005} \\
\hline & $\mathrm{R} \mid 2$ & 0.960184 & & \\
\hline
\end{tabular}

Sources: Primary data are processed, 2017 
Based on the evaluation of outer model as seen on table 2 above, it can be concluded that there is no convergent validity, discriminant validity and internal consistencies problem found in this study. Meanwhile, Cross loadings details for each item can be shown on table 3 below. It shows that cross loadings score for each item are higher than the score of its correlations with other constructs.

Table 3. Cross loadings

\begin{tabular}{ccccc}
\hline & Cl & CU & CA & RI \\
\hline Cl1 & $\mathbf{0 . 8 6 2 9 4 0}$ & 0.553791 & 0.633898 & 0.630561 \\
Cl2 & $\mathbf{0 . 8 7 9 2 1 9}$ & 0.557106 & 0.632162 & 0.627429 \\
Cl3 & $\mathbf{0 . 8 6 5 9 9 2}$ & 0.632228 & 0.623305 & 0.697313 \\
Cl4 & $\mathbf{0 . 8 7 2 8 8 9}$ & 0.589936 & 0.612021 & 0.659989 \\
Cl5 & $\mathbf{0 . 8 8 9 4 1 6}$ & 0.585254 & 0.611627 & 0.747781 \\
Cl6 & $\mathbf{0 . 8 6 4 9 6 4}$ & 0.600054 & 0.628599 & 0.767106 \\
Cl7 & $\mathbf{0 . 8 9 7 5 3 1}$ & 0.558235 & 0.660930 & 0.642339 \\
CU1 & 0.508183 & $\mathbf{0 . 8 4 4 4 9 7}$ & 0.503078 & 0.523172 \\
CU2 & 0.623833 & $\mathbf{0 . 9 1 3 8 4 3}$ & 0.583069 & 0.604044 \\
CU3 & 0.605807 & $\mathbf{0 . 9 0 8 6 8 1}$ & 0.572285 & 0.524908 \\
CU4 & 0.644597 & $\mathbf{0 . 9 2 4 0 4 5}$ & 0.595922 & 0.578688 \\
CA1 & 0.597506 & 0.541140 & $\mathbf{0 . 7 8 4 6 2 3}$ & 0.524954 \\
CA2 & 0.554128 & 0.544436 & $\mathbf{0 . 8 5 3 5 5 3}$ & 0.471815 \\
CA3 & 0.644775 & 0.494246 & $\mathbf{0 . 8 6 4 0 9 2}$ & 0.537219 \\
RI1 & 0.714697 & 0.594009 & 0.583132 & $\mathbf{0 . 9 5 1 7 4 4}$ \\
RI2 & 0.777197 & 0.596342 & 0.587142 & $\mathbf{0 . 9 6 0 1 8 4}$ \\
\hline
\end{tabular}

Source: Primary data are processed, 2017

Table 4. Reliability Test

\begin{tabular}{lcc}
\hline & Composite Reliability & Cronbach's Alpha \\
\hline City Image & 0.958570 & 0.949629 \\
City Uniqueness & 0.943506 & 0.919913 \\
City Authenticity & 0.873208 & 0.781776 \\
Revisit Intention & 0.955005 & 0.905976 \\
\hline
\end{tabular}

Source: Primary data are processed, 2017

In addition, reliability test is measured using internal consistency reliability in PLS, which the value of composite reliability and Cronbach's alpha should be higher than 0.7 . 
Based on table 4 above, both composite reliability and Cronbach's alpha results higher that 0.7 , which means those all three variables are consistent and reliable.

\subsubsection{Evaluation of Inner Model (Structural Model)}

For this study, the evaluation of inner model is indicated by the value of $R$ Square $\left(R^{2}\right)$. The higher the value of $R^{2}$, the more robust the model proposed. In this model, based on PLS measurement, the value of $R^{2}$ for Revisit Intention is 0.653436, hence it can be concluded that the proposed model is robust and hypotheses can be tested.

\subsection{Hypothesis Testing}

In these hypotheses testing, latent variables are measured to evaluate whether there is any significant relationship or not. The hypotheses testing using PLS could be measured from the result of path coefficient and significance of model based on the T-statistics value. In path coefficient, relationship between two variables could be categorized as significance of value of path coefficient is higher than 0.1 and the value of T-statistic is larger than 1.96. The results of hypotheses testing are showed by table 5 .

As we can see from table 5 , there is very strong support for city image component in determining visitors' revisit intention ( $t=0.529425, \beta=5.299967$ ). Meanwhile, different results shown in the relationship between city uniqueness and visitors' revisit intention and between city authenticity and visitors' revisit intention. Both city uniqueness and city authenticity didn't have any support in determining visitors' revisit intention.

\subsection{DISCUSSION}

\subsubsection{The effect of City Image on Visitors' Revisit Intention}

The research result reveals that Malang city image gives a positive support in determining visitors' revisit intention, which means that the more good image leaves in visitors' mind, the more possibilities for visitors' to revisit the city in the future. Seven indicators used to describes city image in this research, that is: personality fit, self-reflection, identification from others, social image, city attractiveness, city likeable and the consistency with self-image considered valid in measuring Malang city image. This result supports Kim \& Lee (2015) research which stated that memorize able image has an important role in leaving a good impression towards visitors' mind and can increase visitors' intention to revisit the same destination. Pratminingsih, et al., (2014) studied also supported by this research results which stated that place image is an important variable that has affect visitors' revisit intention. However, Ramseook-Munhurrun., et al., (2014) research was not supported by this study research. The researchers stated that there is no significant relationship between image and customers' revisit intention, the relationship between those two variables are indirect by using perceived value and satisfaction as the mediation. While the research results in this paper states that there is a direct relationship between image and revisit intention. 
Table 5. Summary of Hypotheses Testing

\begin{tabular}{cccc}
\hline & Path Coefficient & T-Statistics & Hypothesis \\
\hline \hline H1 $(\mathbf{C l}->$ RI) & 0.529425 & 5.299967 & Supported \\
H2 (CU -> RI) & 0.128894 & 1.414973 & Not Supported \\
H3 (CA -> RI) & -0.049461 & 0.517095 & Not Supported \\
\hline
\end{tabular}

\subsubsection{The effect of City Uniqueness on Visitors' Revisit Intention}

The research result explains that Malang city uniqueness did not have significant relationship towards visitors' revisit intention. City uniqueness indicators that are distinct, stands out, very different and unique considered did not attached towards Malang city. Malang city considered did not have something unique compare to the others. This condition affects visitors' willingness to revisit Malang city in the future. H. Qu et al. (2011) studies explained that destination positive image that recorded on visitors' mind including its uniqueness, had a big possibility to revisit in the future and to promote the destination to others. Keller (2013) also has a similar statement which mentioned that a brand should have some uniqueness in order to compete in the market and to attract consumer to choose the brand. Hence, those study results supports that previous study.

\subsubsection{The effect of City Authenticity on Visitors' Revisit Intention}

The research result stated that Malang city authenticity did not have significant relationship towards visitors' revisit intention. Authenticity did not always relate to pure object originality but also the reproduction process originality. Hyojin \& Bonn (2015) describes city authenticity into three indicators: objective authenticity, constructive authenticity and existential authenticity. Based on those three indicators, this study revealed that visitors' considered Malang city did not have something authentic or the authenticity of Malang city cannot affect visitors' intention to revisit Malang city in the future. This study result supports McCannell (1973), Cohen (1988), Naoi (2004) and Kolar \& Zabkar (2007) research that described authenticity as a motivation for visitors' to visit a destination.

\section{CONCLUSION AND SUGGESTION}

\subsection{Conclusion}

Malang city known as one of the famous tourism destination in Indonesia. However, Malang city position as an enclave city which is near Malang district and Batu city, that also has a popular tourism attraction, makes people assumed that Malang city same with those cities. This is reasonable due to those three cities actually part of Malang Raya.

Based on the analysis results, visitors' considered Malang city image as the most attractive factors to revisit Malang city in the future. City image indicators: personality fit, self-reflection, identification from others, social image, city attractiveness, city likeable and the consistency with self-image attached to Malang city and could influence visitors' willingness to revisit. 
Hence, different results reveal for city uniqueness and city authenticity elements. The study analysis stated that Malang city uniqueness and authenticity did not affect visitors' willingness to revisit. From the face to face interview with the respondents, it can conclude that Malang city considered for not having something unique or authentic attraction. The tourism attraction that is offered by Malang city considered as a common attraction compared to other cities. City uniqueness indicators: distinct, stands out, very different and unique and City authenticity indicators: objective authenticity, constructive authenticity and existential authenticity, did not attached to Malang city.

In the relation with City branding, this study results conclude that city branding has an influence towards visitors' revisit intention. Malang city branding that is Beautiful city, which means Malang is a pretty and beautiful city, considered feasible to describe and to promote Malang city image. The efforts that is conducted by Malang city to realize this branding, result in visitors' willingness to revisit Malang city.

\subsection{Suggestion}

Our findings reveal that Malang city image are playing an important part in a city marketing strategy, due to its influenced visitors' revisit intention. Hence, decision maker, destination manager, or in this case the related government, suggest focusing their strategies in developing and promoting Malang city image. Destination manager should conduct image marketing strategies and doing partnership with travel agent, tour operators and advertising media in order to promote the appropriate image to the traveling public.

Destination manager requires designing a feasible marketing program that could sell the city strength. This strategy can communicate the city advantage to public. Regarding Malang city branding, that is Malang Beautiful city, based on the research results, this branding considered suitable and feasible to describe Malang city advantage.

This study has limitation. The study is conducted only in one enclave city, which already branded itself based on image attributes. Future research might include other enclave cities as a comparison and include other cities which already branded themselves along other dimensions or even cities that is still not conduct city branding as their tourism strategies.

This study also examined the influence of city branding on visitors' revisit intention without any mediation variable. Future research might explore this relationship by using mediation, such as satisfaction in order to gain a deeply research results. And for the last, this study has a limitation on the number of respondents due to limited time for conducting this study. Respondents from foreign countries visitors' also can be added. The more various respondents, the more accurate research presents. 


\section{REFERENCES}

Aminudin Muhammad. 2016. Beautiful Malang Branding City Kota Menjual Keindahan, http://www.detik.com/news/berita-jawa-timur/3207407/ beautifulmalang-branding-city-kota-menjual-keindahan. Mei 2016.

Ashworth, G.J. 2009. The Instruments of Place Branding: How Is It Done? European Spatial Research and Policy, 16(1): 9-22.

Badan Pusat Statistik (Indonesia Central Bureau of Statistics). 2016. Jumlah Kedatangan Wisatawan Mancanegara Ke Indonesia Menurut Pintu Masuk, 1997 - 2015, https://www.bps.go.id/linkTabelStatis/view/id/1387. January 2017.

Baloglu, S. and Brinberg, D. 1997. Affective Images of Tourism Destinations, Journal of Travel Research, pp.11-15.

Barnes, S.J., Mattsson, J. and Sorensen, F. 2016. Remembered Experiences and Revisit Intentions: A Longitudinal Study of Safari Park Visitors, Tourism Management, 57, pp.286-294.

Basaran, U. 2016. Examining the Relationship of Cognitive, Affective and Conative Destination Image: A Research of Safranbolu, Turkey, International Business Research, 9(5), pp.164-179.

Berci, F, Mommaas, H and Synghel, K. 2002. City branding: Image building and building images. NAI Publisher. Rotterdam.

Beverland, M.B., Lindgreen, A. and Vink, M.W. 2008. Projecting Authenticity through Advertising: Consumer Judgments of Advertisers' Claims, Journal of Advertising, 37, pp.5-15.

Boo, S., Busser, J. and Baloglu, S. 2010. A Model of Customer-based Brand Equity and Its Application to Multiple Destinations, Tourism Management, 30, pp.219-231.

Bowen, J.T. \& Shoemaker, S. 1998. Loyalty: A Strategic commitment, Cornell hotel and restaurant administration quarterly, 39(1), pp.12-25.

Boyd, J.M. (2012), Authenticity and Aura. A Benjaminian Approach to Tourism, Annals of Tourism Research, 39(1), pp.269-289.

Cesya Rizkika P. and Ananda Sabil H. 2014. The Determinants of Visitor's Revisit Intention: A Lesson from ljen Car Free Day, Asia-Pacific Management and Business Application, 3(2), pp.74-85.

Chen, C. and Tsai, D. 2007. 'How destination image and evaluative factors affect behavioural intentions. Tourism Management, 28(4), pp.1115-1122. 
Chin, W.W. and Newsted, P.R. 1999. Structural Equation Modelling Analysis with Small Samples Using Partial Least Squares, Statistical Strategies for Small Sample Research. Sage Publications. London.

Cohen, Eric. 1988. Authenticity and Commoditization in Tourism. Annals of Tourism Research. 15(2), pp.371-386.

Cronin, J.J., Brady, M.K. and Hult, M.K. 2000. Assessing the effects of quality, value, and customer satisfaction on consumer behavioral intentions in service environments, Journal of Retailing, 76(2), pp.193-218.

Evans, G. 2003. Hard-branding the Cultural City - From Prado to Prada. International Journal of Urban and Regional Research. 27 (2). pp.417-440

Getty, J.M. and Thompson, K.N. 1994. The relationship between quality, satisfaction and recommending behaviour in lodging decision, Journal of Hospitality and Leisure Marketing, 2(3), pp.3-22.

Gurbuz, E. 2008. Retail store branding in Turkey: Its effect on perceived quality, satisfaction and loyalty, Euromed Journal of Business, 3(3), pp.286-304.

H.Chou. 2013. The Effect of Visitor's consumption experience and tourism image on Tourist Satisfaction and Revisit Intention of Taiwan's Night Market, GSTF International Journal on Business Review, 3(1), pp.129-134.

H. Qu, L.H. Kim and H.H. Im. 2011. A Model of Destination Branding: Integrating the Concepts of the Branding and Destination Image, Tourism Management, 32, pp.465-476.

Hatch, M.J., Schultz, M. 2008. The Dynamics of Organizational Identity, Human Relations, 55(8), pp.989-1018.

Hyojin, K. and Bonn, M.A. 2015. Authenticity Do Tourist perceptions of winery experiences affect behavioral intentions?. International Journal of Contemporary Hospitality Management, 28(4), pp.839-859.

Jones, S. 2010. Negotiating Authentic Objects and Authentic Selves. Beyond the Deconstruction of Authenticity, Journal of Material Culture, 15 (2), pp.181-203.

Kandapully, J. and Suhartanto, D. 2000. Customer loyalty in the hotel industry: the role of customer satisfaction and image, International Journal of Contemporary Hospitality Management, 12(6), pp.346-351.

Kavaratzis, M and Ashworth, G.J. 2005. City Branding: An effective assertion of identity or a transitory marketing trick? Tijdschrift voor Economische en Sociale Geografie, 96(5), pp.506-514.

Kavaratzis, M. and Ashworth, G.J. 2007. Partners in Coffeeshops, Canals, and Commerce: Marketing the City of Amsterdam. Cities, 24(1), pp.16-25. 
Keller, K.L. 2013. Strategic Brand Management. Building, Measuring and Managing Brand Equity. Pearson Education Limited. England.

Kementerian Pariwisata Republik Indonesia (Ministry of Tourism). 2017. Perkembangan wisatawan Nasional tahun 2011 - 2016. http://www.kemenpar.go.id/asp/ detil.asp?c=112\&id=1358. January 2017.

Kemp, E., Childers, C.Y. and Williams, K.H. 2012. Place Branding: Creating SelfBrand Connections and Brand Advocacy, Journal of Product and Brand Management, 21(7), pp.508-515.

Kim, H., and Sanggun, L. 2015. Impacts of city personality and Image on Revisit Intention. International Journal of Tourism Cities, 1(1), pp.50-69.

Kolar, T. and Zabkar, V. 2007. The Meaning of Tourists' Authentic Experiences for The Marketing of Cultural Heritage Sites, Economic and Business Review, 9(3), pp.235-256.

Kotler, P., Rein, I., and Haider, D. 1993. Marketing Places: Attracting Investment, Industry, and Tourism to Cities, States and Nations. MaxWell Macmillan Int, New York.

Langer, R. 2001. Place images and place marketing, Working Paper, vol 2001-03, Copenhagen Business School, Copenhagen.

Lee, C. 2015. Tourist Satisfaction with Factory Tour Experience. International Journal of Culture, Tourism and Hospitality Research, 9(3), pp.261-277.

Lin, H. 2011. A Multidimensional Customer-based Brand Equity and Its Application to Religious Events: The Case of Mazu. A Dissertation in Hospitality Administration. University of Texas Tech.

McCannell, Dean. 1973. Staged Authenticity: Arrangements of Social Space in Tourist settings. American Journal of Sociology, 79(3), pp.589-603.

Mkono, M. 2012. A Netnographic Examination of Constructive Authenticity in Victoria Falls Tourist (Restaurant) Experiences. International Journal of Hospitality Management, 31, pp.387-394.

Morgan, N, Pritchard, A. and Pride, R. 2002. Destination branding: Creating the unique destination preposition. Butterworth-Heinemann. Oxford.

Naoi, Taketo. 2004. Visitors' evaluation of a Historical District: The Roles of Authenticity and Manipulation. Tourism and Hospitality Research. 5(1), pp.4563.

Netemeyer, R.G., Krishnan B., Pullig C., Wang G., Yagci M., Dean D., Ricks J. and Wirth F. 2004. Developing and Validating Measures of Facets of CustomerBased Brand Equity. Journal of Business Research, 5, pp.209-224. 
Pratminingsih, S.A., Rudatin, C.L. and Rimenta, T. 2014. Roles of Motivation and Destination Image in predicting Tourist Revisit Intention: A Case of BandungIndonesia. International Journal of Innovation, Management and Technology, 5(1), pp.19-24.

Quintal, V.A. and Polczynski, A. 2010. Factors Influencing Tourists' Revisit Intentions. Asia Pacific Journal of Marketing and Logistics, 22(4), pp.564-578.

Ram, Y., Bjork, P. and Weidenfeld, A. 2016, Authenticity and Place Attachment of Major Visitor Attractions. Tourism Management, 52, pp.110-122.

Ramseook-Munhurrun, P., Seebaluck, V.N. and Naidoo, P. 2015. Examining the Structural Relationships of destination image, perceived value, tourist satisfaction and loyalty: Case of Mauritius. Procedia-Social and Behavioral Sciences, 175, pp.252-259.

Riza, M., Doratli, N. \& Fasli, M. 2012. City branding and Identity. Procedia-Social and Behavioral Sciences, 35, pp.293-300.

Robinson K.A., Saldanha I.J. and Mc Koy N.A. 2011. Identification of Research Gaps from Evidence-based Guidelines: A Pilot Study in Cystic Fibrosis. International Journal of Technology Assessment in Health Care, 27(3), pp.247-253.

Sirgy, M. \& Su, C. 2000. Destination Image, Self-Congurity and Travel Behavior: Toward an Integrative Model, European Advances in Consumer Research, 38, pp.340-352.

So, J.T., Parsons, A.G., and Yap, S. 2013. Corporate branding, emotional attachment and brand loyalty: the case of luxury fashion branding. Journal of Fashion Marketing and Management, 17(4), pp.403-423.

Steiner, C.J. and Reisinger, Y. 2006. Understanding Existential Authenticity. Annals of Tourism Research, 33 (2), pp.299-318.

Van Gelder, S. (2008). An introduction to city branding. Placebrands limited. Netherlands.

World Tourism Organization. 2016. UNWTO Tourism Highlights, 2016 Edition.

Zhang, L., and Zhao, S.X. 2009. City branding and the Olympic effect: A case study of Beijing. Cities, 26, pp.245-254. 